\title{
EXPERIMENTAL STUDIES ON PROPERTIES OF GEO-POLYMER CONCRETE WITH GGBS AS A BINDER
}

\author{
K.Surya Teja ${ }^{1}$, M.Tagore Sunil Sai ${ }^{2}$, Y.Himath Kumar $^{3}$ \\ ${ }^{l}$ B.Tech Civil Engineering, $K$ L University, Vaddeswaran, Guntur, Andhrapradesh, INDIA \\ ${ }^{2}$ B.Tech Civil Engineering, $K$ L University, Vaddeswaran, Guntur, Andhrapradesh, INDIA \\ ${ }^{3}$ Assistant Professor, Department of Civil Engineering, K L University, Vaddeswaran, Guntur, Andhrapradesh, INDIA
}

\begin{abstract}
This paper elucidates an alternative to conventional concrete we introduced Geopolymer concrete ie replacing cement with pozzolanic materials like GGBS and fly ash. In our study we incorporated GGBS with cement at cent percent and alkali solutions like Sodium hydroxide and Sodium silicate are used in ratio 1:2 as binders. We designed for 8 \&10 molarity of sodium hydroxide. Compressive strength and flexural strength are found for Geopolymer concrete for 7 and 28 days of curing. The overall aim is to reduce usage of cement as well as to reduce pollution because one ton of cement produce one ton of carbon dioxide. This type of concrete improves use of waste products of industry in our construction industry.
\end{abstract}

Keywords:- GGBS , Fly Ash, Cement, Geopolymer Concrete, Compression Strength, Flexural strength.

\section{INTRODUCTION}

Romans used geopolymer concrete in ancient days but it was invented by Davidovits in 1978. Concrete that is produced using aluminate and silica as binding materials is called Geopolymer concrete. Metal Slag, ash products are mainly used because they are waste products and they are not useful for environment. These waste materials are directly mixed within the concrete and have a similar binding properties to that of cement. Usage of activators like Sodium hydroxide and Sodium silicate increases binding property to that of cement. This concrete has more additional advantages than conventional concrete. It has more life and minimizes money spent on repairs and maintenance.. Properties like high compressive, flexural, split tensile strength are noted for geopolymer concrete. Curing of geopolymer concrete is fast than nominal concrete.Geopolymer concrete gains its maximum strength with in 7 days. In geopolymer concrete polymerization takes place between alkaline liquid and earth materials like flyash or GGBS. These are formed in chain like structures during polymerization and they are linked by covalent type of bond. Geopolymers have a similar chemical composition like Zeolite. Chemicals like Sodium hydroxide/ Potassium hydroxide/Sodium silicate/ Potassium silicate are commonly used alkaline liquids to enhance reaction rate in concrete. Sodium hydroxide and Sodium silicate are preferred because they are affordable and commonly available in market. Ground granulated blast furnace slag (GGBS) is a byproduct from the blast-furnaces during manufacture of iron products. During the process, slag was formed and it is then dried and ground to a fine powder.

\section{RAW MATERIALS}

\section{GGBS:-}

GGBS we opted is taken from JSW( Jindal Steel works) and its chemical composition are:-
Table 1 Properties of GGBS Aggregates:- Coarse aggregate:- $10 \mathrm{~mm}$ size aggregate are used

\begin{tabular}{|l|l|}
\hline $\mathrm{CaO}$ & $37.34 \%$ \\
\hline $\mathrm{Al}_{2} \mathrm{O}_{3}$ & $14.42 \%$ \\
\hline $\mathrm{Fe}_{2} \mathrm{O}_{3}$ & $1.11 \%$ \\
\hline $\mathrm{SiO}_{2}$ & $37.73 \%$ \\
\hline $\mathrm{MgO}$ & $8.71 \%$ \\
\hline $\mathrm{MnO}$ & $0.02 \%$ \\
\hline
\end{tabular}

Table 2 Properties of Coarse aggregate

\begin{tabular}{|l|l|}
\hline Specifikc gravity & 3.10 \\
\hline Bulk Density $\left(\mathrm{kg} / \mathrm{m}^{3}\right)$ & 1.77 \\
\hline Flakiness & $35.51 \%$ \\
\hline Elongation & $20.28 \%$ \\
\hline
\end{tabular}

Table 3 Properties of Fine aggregate Fine aggregate:-

\begin{tabular}{|l|l|l|}
\hline I.S. Sieve (mm) & $\begin{array}{l}\text { Percentage } \\
\text { Passing } \\
\text { through I.S. } \\
\text { Sieve }\end{array}$ & $\begin{array}{l}\text { Percentage } \\
\text { Passing } \\
\text { I.S. Sieve } \\
\text { as per IS } \\
383-1970\end{array}$ \\
\hline 10 & & $90-100$ \\
\hline 4.75 & 98.8 & $85-100$ \\
\hline 2.36 & 97.6 & $75-100$ \\
\hline 1.18 & 92.2 & $60-79$ \\
\hline 600 micron & 60.8 & $12-40$ \\
\hline 300 micron & 17.2 & $0-10$ \\
\hline 150 micron & 1.8 & 3 \\
\hline Zone & \multicolumn{2}{|c|}{2.31} \\
\hline Fineness modulus & \multicolumn{2}{|c|}{2.735} \\
\hline Specific Gravity & \multicolumn{2}{|c|}{1.72} \\
\hline Bulk Density Kg/m ${ }^{3}$ & \multicolumn{2}{|c|}{} \\
\hline
\end{tabular}




\section{Alkaline solutions:-}

Sodium hydroxide \& Sodium Silicate are preferred as Alkaline liquids at ratio 1:2. Sodium hydroxide flakes $(97 \%)$ purity and Sodium Silicate $(8.5 \%)$ of sodium oxide are used in present study.

\section{Methodology:-}

Preparation of Alkaline solution:-

8 and 10 molarity of Sodium Hydroxide are prepared.Sodium hydroxide has a molecular weight of 40.To prepare 8 and 10 molar of Sodium Hydroxide solution 320 gms and 400gms of flakes are dissolved in distilled water to form 1 liter solution. To prepare solution a conical flask is taken and sodium hydroxide flakes are mixed within the water to prepare 1 liter of sodium hydroxide solution

\section{Mix design:-}

We adopted a trail mix design for this experiment. Assume unit weight of Geopolymer concrete is $2400 \mathrm{~kg} / \mathrm{m}^{3} .75 \%$ of its composition is comprised with aggregates. In that $75 \%$ only $70 \%$ is comprised with coarse aggregate and $30 \%$ with fine aggregate. Liquid to GGBS ratio is 0.45 . Sodium hydroxide \& Sodium Silicate solutions are taken in ratio 1:2. Below table illustrates composition for $1 \mathrm{~m}^{3}$ of Geopolymer concrete.

Table 4 Proportions of mix for $1 \mathrm{~m}^{3}$

\begin{tabular}{|l|l|}
\hline Coarse aggregate & $1260 \mathrm{~kg} / \mathrm{m}^{3}$ \\
\hline Fine aggregate & $540 \mathrm{~kg} / \mathrm{m}^{3}$ \\
\hline GGBS & $413.8 \mathrm{~kg} / \mathrm{m}^{3}$ \\
\hline Sodium hydroxide & $62.1 \mathrm{~kg} / \mathrm{m}^{3}$ \\
\hline Sodium Silicate & $124.2 \mathrm{~kg} / \mathrm{m}^{3}$ \\
\hline
\end{tabular}

Mixing, Casting, Curing:-

Cubes of size $150 \times 150 \times 150 \mathrm{~mm}$ and Beams of size 500x100x100 mm are used for this study. Geopolymer Concrete was prepared in a tray and its raw materials are weighed. First coarse and fine aggregates, GGBS are mixed for 5 to 10 minutes in dry condition later alkaline solution is added and fused for 6 minutes. After compaction on vibrating table entire mould is left for 2 days and then it is demould. Ambient curing technique is followed and cured for 7 and 28 days. After curing Compression and Flexural strength are found out.

\section{RESULT}

8 Molarity of Sodium hydroxide:-

Compressive strength for 7 and 28 days curing

\begin{tabular}{|l|l|l|}
\hline Sample No & 7 days $\left(\mathrm{N} / \mathrm{mm}^{2}\right)$ & 28 days $\left(\mathrm{N} / \mathrm{mm}^{2}\right)$ \\
\hline 1 & 23.11 & 25.28 \\
\hline 2 & 21.77 & 24.85 \\
\hline 3 & 20.88 & 24.85 \\
\hline Average & 21.92 & 25 \\
\hline
\end{tabular}

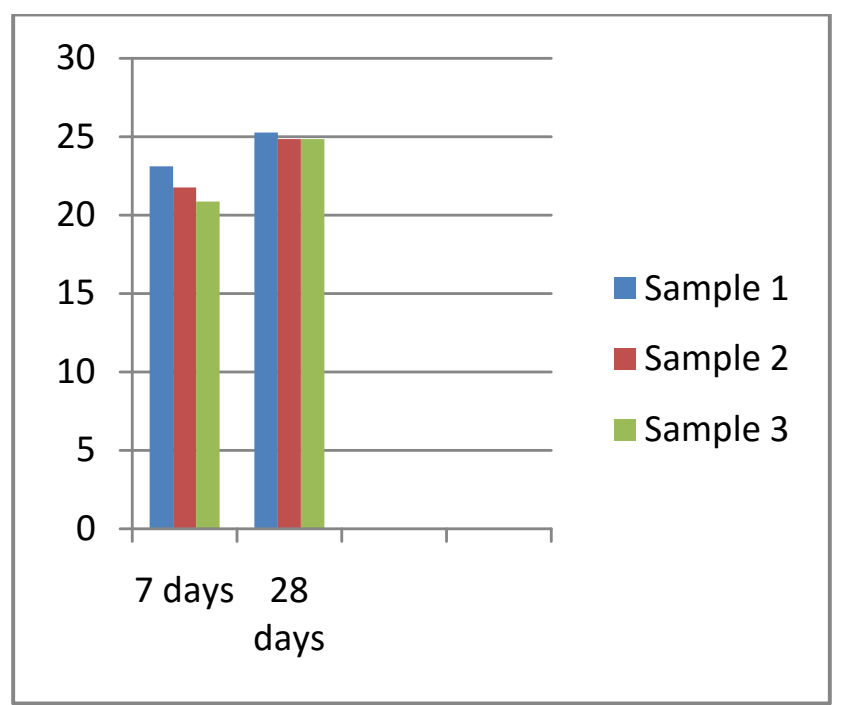

Fig 1: Compressive strength comparison for three samples of 7 days and 28 days cured cubes

Flexural strength for 7 and 28 days curing

\begin{tabular}{|l|l|l|}
\hline Sample No & 7 days $\left(\mathrm{N} / \mathrm{mm}^{2}\right)$ & 28 days $\left(\mathrm{N} / \mathrm{mm}^{2}\right)$ \\
\hline 1 & 5.395 & 6.687 \\
\hline 2 & 4.905 & 7.848 \\
\hline 3 & 4.905 & 7.35 \\
\hline Average & 5.06 & 7.29 \\
\hline
\end{tabular}

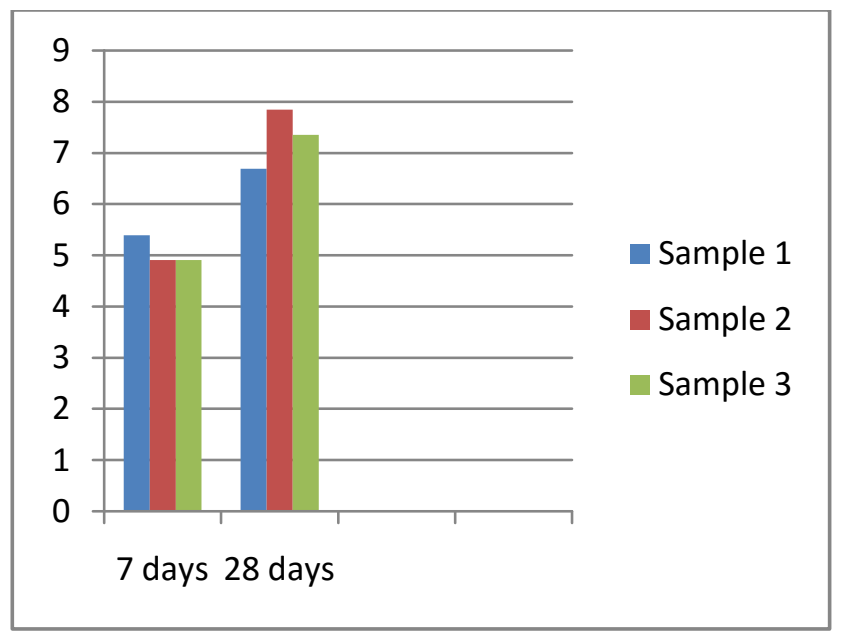

Fig 2: Flexural strength comparison for three samples of 7 days and 28 days cured cubes

10 Molarity of Sodium hydroxide:-

Compressive strength for 7 and 28 days curing

\begin{tabular}{|l|l|l|}
\hline Sample No & 7 days $\left(\mathrm{N} / \mathrm{mm}^{2}\right)$ & 28 days $\left(\mathrm{N} / \mathrm{mm}^{2}\right)$ \\
\hline 1 & 28.77 & 33.13 \\
\hline 2 & 29.21 & 35.31 \\
\hline 3 & 28.34 & 36.62 \\
\hline Average & 28.77 & 35.02 \\
\hline
\end{tabular}




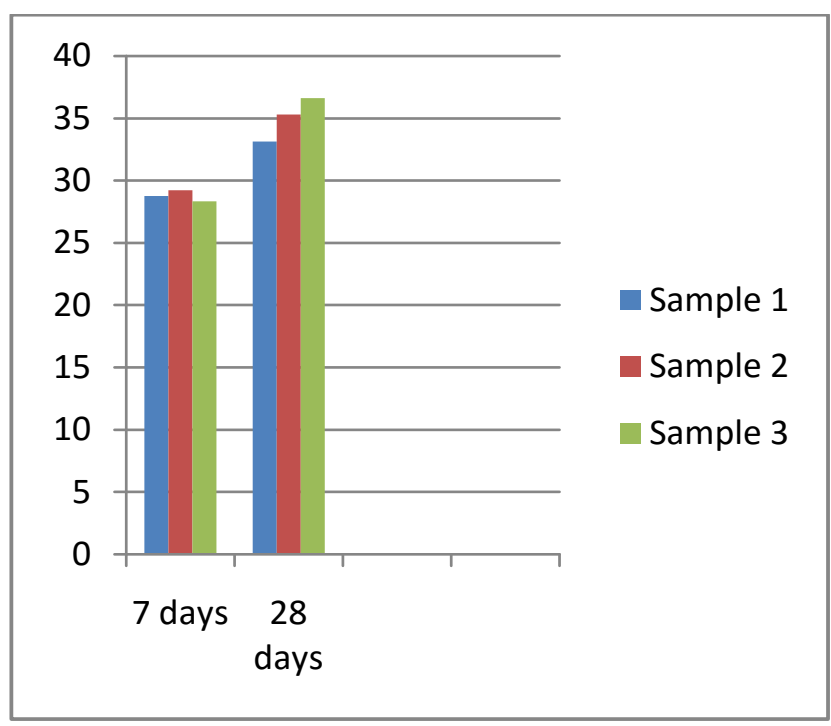

Fig 3: Compressive strength comparison for three samples of 7 days and 28 days cured cubes

Flexural strength for 7 and 28 days curing

\begin{tabular}{|l|l|l|}
\hline Sample no & 7 days $\left(\mathrm{N} / \mathrm{mm}^{2}\right)$ & 28 days $\left(\mathrm{N} / \mathrm{mm}^{2}\right)$ \\
\hline 1 & 10.79 & 12.75 \\
\hline 2 & 10.79 & 10.79 \\
\hline 3 & 9.81 & 9.81 \\
\hline AVG & 10.46 & 11.11 \\
\hline
\end{tabular}

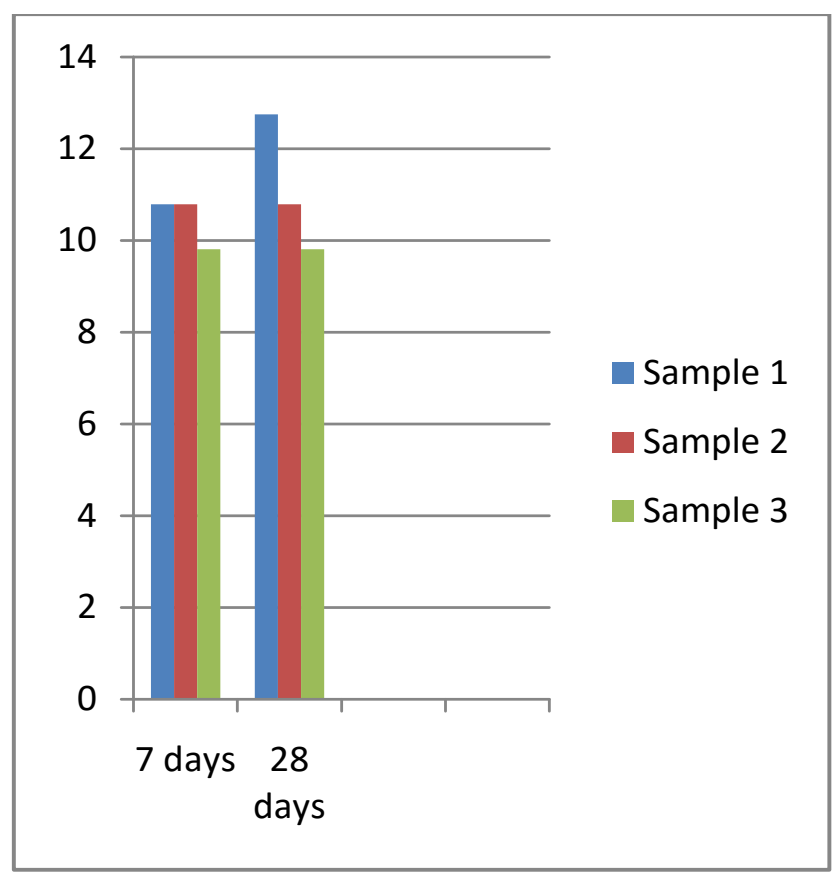

Fig 4: Flexural strength comparison for three samples of 7 days and 28 days cured cubes

\section{CONCLUSION}

From the above results compressive strength and flexural strength are increased when molarity of sodium hydroxide is increased in solution.
Curing for 7 days compressive strength reaches to $80 \%$ of its strength.

For 7days and 28 days of curing flexural strength values looked alike in some cases.

\section{REFERENCES}

[1]. V.Supraja,,M.Kanta Rao ,Experimental study on GeoPolymer concrete incorporating GGBS, International Journal of Electronics, Communication \& Soft Computing Science and Engineering, ISSN: 22779477, Volume 2, Issue 2.

[2]. Mohamed Aquib Javeed, Studies on Mix Design of Sustainable Geo-Polymer Concrete International Journal of Innovative Research in Engineering \& Management (IJIREM) ISSN: 2350-0557, Volume-2, Issue-4, July 2015

[3]. Ahmed Mohmed Ahmed, Physical Properties of Geopolymer Concrete Incorporating Silica Fume and Ground Granulated Blast-Furnace Slag, International Journal of Science and Research (IJSR) ISSN (Online): 2319-7064 Index Copernicus Value (2013): 6.14 | Impact Factor (2013): 4.438

[4]. A.Maria Rajesh, M.Adams Joe,Roy Mammen, Study of the Strength Geopolymer Concrete with Alkaline Solution of Varying Molarity, IOSR Journal of Engineering (IOSRJEN) ISSN (e): 2250-3021, ISSN (p): 2278-8719 Vol. 04, Issue 06 (June. 2014)

[5]. Madheswaran C, Gnanasundar, Gopalakrishnan, Effect of molarity in geopolymer concrete, International Journal Of Civil And Structural Engineering, Volume 4, No 2, 2013

[6]. P.Vignesh K.Vivek An Experimental Investigation On Strength Parameters Of Flyash Based Geopolymer Concrete With GGBS International Research Journal of Engineering and Technology (IRJET) e-ISSN: 23950056 Volume: 02 Issue: 02 | May-2015

[7]. GanapatiNaidu.P,A.S.S.N.Prasad,S.Adiseshu P.V.V.Satayanarayana, A Study on Strength Properties of Geopolymer Concrete with Addition of GGBS, International Journal of Engineering Research and Development eISSN : 2278-067X,Volume 2, Issue 4 (July 2012), PP. 19-28

[8]. Rohit Zende, Mamatha.A Study of Flyash and GGBS Geopolymer concrete under Ambient curing,International Journal of Emerging Technologies and Innovative Research,ISSN 2349-5162,Vol2,Issue7

[9]. L.Krishnan ,S.Karthikeyan , S.Nathiya, K. Suganya, Geopolymer Concrete An Eco-Friendly Construction Material JRET: International Journal of Research in Engineering and Technology eISSN: 2319-1163 pISSN: 2321-7308

[10]. Mohammed Areeb Qidwai, To Study The Properties Of Geopolymer Concrete Using GGBS, Journal of Engineering Research and Studies E-ISSN0976-7916 


\section{BIOGRAPHIES}

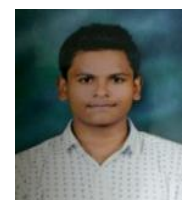

Koraganji Suryateja

Persuing 1v/1v BTech Civil Engineering, Kl

University.

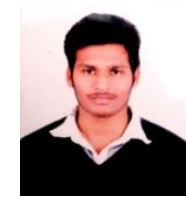

M.Tagore Sunil Sai

Persuing 1v/1v BTech Civil Engineering, Kl

University.

\section{Y.Himath Kumar}

Assistant Professor, Kluniversity 